Original Article

Artigo Original

Alessandra Terra Vasconcelos Rabelo ${ }^{1}$ Juliana Nunes Santos ${ }^{2}$ Rafaella Cristina Oliveira ${ }^{1}$ Max de Castro Magalhães ${ }^{3}$

Keywords

Acoustics

Noise

Speech Intelligibility

Learning

School Health

Descritores

Acústica

Ruído

Inteligibilidade da Fala

Aprendizagem

Saúde Escolar

Correspondence address:

Max de Castro Magalhães

Departamento de Engenharia de Estruturas,

Universidade Federal de Minas Gerais

Avenida Antônio Carlos, 6.627, Campus

Pampulha, Belo Horizonte (MG), Brasil, CEP: 31270-901.

E-mail: maxdcm@gmail.com

Received: 02/17/2014

Accepted: 08/04/2014

CoDAS 2014;26(5):360-6

\section{Effect of classroom acoustics on the speech intelligibility of students}

\author{
Efeito das características acústicas de salas de aula \\ na inteligibilidade de fala dos estudantes
}

\begin{abstract}
Purpose: To analyze the acoustic parameters of classrooms and the relationship among equivalent sound pressure level $\left(L_{\text {eq }}\right)$, reverberation time $\left(\mathrm{T}_{30}\right)$, the Speech Transmission Index (STI), and the performance of students in speech intelligibility testing. Methods: A cross-sectional descriptive study, which analyzed the acoustic performance of 18 classrooms in 9 public schools in Belo Horizonte, Minas Gerais, Brazil, was conducted. The following acoustic parameters were measured: $L_{\text {eq }}, \mathrm{T}_{30}$, and the STI. In the schools evaluated, a speech intelligibility test was performed on 273 students, $45.4 \%$ of whom were boys, with an average age of 9.4 years. The results of the speech intelligibility test were compared to the values of the acoustic parameters with the help of Student's $t$-test. Results: The $L_{\text {eq }}, \mathrm{T}_{30}$, and STI tests were conducted in empty and furnished classrooms. Children showed better results in speech intelligibility tests conducted in classrooms with less noise, a lower $\mathrm{T}_{30}$, and greater STI values. The majority of classrooms did not meet the recommended regulatory standards for good acoustic performance. Conclusion: Acoustic parameters have a direct effect on the speech intelligibility of students. Noise contributes to a decrease in their understanding of information presented orally, which can lead to negative consequences in their education and their social integration as future professionals.
\end{abstract}

\section{RESUMO}

Objetivo: Analisar os parâmetros acústicos de salas de aula e relação do nível de pressão sonora equivalente $\left(\mathrm{L}_{\mathrm{eq}}\right)$, tempo de reverberação $\left(\mathrm{T}_{30}\right)$ e Speech Transmission Index (STI) com o desempenho de estudantes em teste de inteligibilidade de fala. Métodos: Estudo transversal descritivo com análise do desempenho acústico de 18 salas de aula de nove escolas públicas do município de Belo Horizonte. Foi realizada medição dos parâmetros acústicos de $\mathrm{L}_{\text {eq }}, \mathrm{T}_{30}$ e STI. Foi aplicado um teste de inteligibilidade de fala em 273 estudantes das nove salas de aula avaliadas, com média de idade de 9,4 anos, sendo $45,4 \%$ do sexo masculino. Os resultados do teste de inteligibilidade de fala foram relacionados aos valores dos parâmetros acústicos por meio do teste $t$ de Student. Resultados: Os parâmetros de $\mathrm{L}_{\text {eq }}, \mathrm{T}_{30}$ e STI foram obtidos nas salas de aulas vazias e mobiliadas. As crianças apresentaram melhores resultados no teste de inteligibilidade de fala nas salas de aula com menor ruído, menor tempo de reverberação e maior STI. A maioria das salas de aula não atende às recomendações das normas regulamentadoras para bom desempenho acústico. Conclusão: Os parâmetros acústicos influenciam diretamente na inteligibilidade de fala dos estudantes, sendo que o ruído contribuiu para diminuição da compreensão da mensagem oral por parte dos estudantes, o que pode trazer consequências negativas para o percurso escolar e inserção social do futuro profissional.

Study was carried out at the Speech-Language Pathology and Audiology and Structural Engineering Departments, Universidade Federal de Minas Gerais - UFMG - Belo Horizonte (MG), Brazil.

(1) Universidade Federal de Minas Gerais - UFMG - Belo Horizonte (MG), Brazil.

(2) Speech-Language Pathology and Audiology Department, Universidade Federal de Minas Gerais - UFMG Belo Horizonte (MG), Brazil.

(3) Structural Engineering Department, Universidade Federal de Minas Gerais - UFMG - Belo Horizonte (MG), Brazil.

Financial support: Fundação de Amparo à Pesquisa do Estado de Minas Gerais - FAPEMIG.

Conflict of interests: nothing to declare. 


\section{INTRODUCTION}

Noise in classrooms is a much discussed topic nowadays due to health risks and possible interferences that it can cause in school activities $^{(1,2)}$. It is known that ideal teaching and learning situations depend on good acoustic conditions.

Among the adverse effects caused by noise in the classroom, the physical, emotional, and educational losses are noteworthy. Also, changes in hearing thresholds, tinnitus, fatigue, greater effort for concentration, loss of part of the content taught, vocal effort, and unintelligible speech may occur ${ }^{(3)}$.

Noise interferes with oral communication, a factor that competes with the teacher's voice, which compromises the intelligibility of speech, being able to harm both the students and the teachers ${ }^{(3)}$. These professionals need to increase the volume of their voice to be understood and, at the same time, the efforts of students to understand the spoken message are much higher ${ }^{(3,4)}$.

Many of the noise problems in classrooms may be aggravated by inadequate room acoustics. Acoustic parameters, such as the equivalent sound pressure level $\left(L_{\mathrm{eq}}\right)$, reverberation time $\left(\mathrm{T}_{30}\right)$, and Speech Transmission Index (STI), can be used to assess whether a room is within the ideal standards for a good acoustic condition for learning. There are rules that regulate these parameters and that can be used in projects for the construction of school environments with proper acoustics ${ }^{(5,6)}$. The American Standard ANSI S12.60 (2010), for example, sets the noise measured in unoccupied rooms must not exceed $35 \mathrm{~dB}$, and the reverberation time should be no more than $0.6 \mathrm{~s}^{(5)}$. In Brazil, there is still no specific standard for classrooms. NBR 10152 (1987), which is a Brazilian standard for noise in environments and is currently under revision, intends to modify the currently prescribed limit of noise in classrooms from $40 \mathrm{~dB}(\mathrm{~A})$ (comfort level) to $50 \mathrm{~dB}(\mathrm{~A})$ (acceptable level) to $35 \mathrm{~dB}(\mathrm{~A})^{(7)}$.

When classrooms are built following a careful acoustic design, during communication the difference between the signal (speech) and the noise will be $+15 \mathrm{~dB}$, that is, the speech signal will be $15 \mathrm{~dB}$ above the noise. In these rooms, theoretically, all students will have full auditory access to the spoken message $^{(8)}$. For the teacher's speech to be intelligible in a room where noise is around $45 \mathrm{~dB}(\mathrm{~A})$, as is usually suggested by the standards, the teacher would have to raise their voice to around $65 \mathrm{~dB}$ and, to speak loudly, but without shouting, could reach up to $75 \mathrm{~dB}(\mathrm{~A})$. Noise is considered unhealthy when it reaches levels above $70 \mathrm{~dB}(\mathrm{~A})$, which can cause physiological reactions such as stress, stroke, hearing loss, and dysphonia ${ }^{(9)}$.

The Acoustical Society of America, from the analysis of several studies, also recommend that overall sound levels (target speech + noise) should not be more than $70 \mathrm{~dB}(\mathrm{~A})$ across the room, as measured using a sound level meter set to the A-weighting scale ${ }^{(8)}$.

However, values reported in earlier studies are above $35 \mathrm{~dB}(\mathrm{~A})$, which is the recommended value. In national studies, the values found were $46.6 \mathrm{~dB}(\mathrm{~A})$ in João Pessoa ${ }^{(4)}$, $50-71 \mathrm{~dB}(\mathrm{~A})$ in the Federal District ${ }^{(10)}, 51.1-63.2 \mathrm{~dB}(\mathrm{~A})$ in Paraná ${ }^{(11)}$, and $40.6-50.6 \mathrm{~dB}(\mathrm{~A})$ in Araraquara ${ }^{(12)}$. In international studies, the values were found to be between 69.4 and $74.68 \mathrm{~dB}(\mathrm{~A})^{(13)}$ and $47 \mathrm{~dB}(\mathrm{~A})$ in the $\mathrm{UK}^{(14)}$.
Projects for new classrooms need to follow these parameters and also an acoustic planning, which is a more economical and effective way. Subsequent corrective actions always lead to higher costs and more difficult solutions.

For further measures to be taken and more specific laws to be created for classrooms, scientific studies are necessary to present the actual situation of Brazilian classrooms. Some studies have been conducted in Brazil. However, they were limited to the measurement of some acoustic parameters without relating them to the listener's performance as a student.

The investigation of factors related to the teaching-learning process can assist managers, educators, and speech therapists to plan actions, as many complaints of students regarding learning difficulties may be aggravated or caused by exposure to excessive noise ${ }^{(15)}$.

Thus, this study sought to evaluate the acoustical characteristics of classrooms and noise present in them, as well as their relationship with a student's performance in a speech intelligibility test.

\section{METHODS}

This was a descriptive, cross-sectional study analyzing the acoustic quality of classrooms in the municipality of Belo Horizonte. Nine public schools were selected in the municipality because of their different features of construction and location in different regions and in different types of road (street, avenue, or highway) of the city, seeking to encompass various situations encountered in municipal schools. In each school, two classrooms were evaluated. Thus, the sample consisted of 9 schools and 18 classrooms.

The study was approved by the Municipal Department of Education and the research ethics committee of the Universidade Federal de Minas Gerais (UFMG), under Protocol no. 352/2012. Caretakers of the children invited to participate in the study signed the informed consent form agreeing to participate.

\section{Evaluation of acoustic parameters}

The acoustics of classrooms was evaluated from observation of the characteristics of rooms and measurement of acoustic parameters $L_{\text {eq }}$, reverberation time $\left(\mathrm{T}_{30}\right)$, and STI. The instruments used in the measurements had their calibration certificates within the validity period and were transported to the site of measurement in special boxes.

In the following sections the criteria detailed were used for each acoustic parameter.

\section{Equivalent sound pressure level}

The $L_{\text {eq }}$ is the level that represents the amount of sound energy over a period of time, that is, it is a time average of the sound pressure level in a certain environment. It is given in $\mathrm{dB}(\mathrm{A})^{(5)}$.

The $L_{\mathrm{eq}}$ was measured using a digital sound pressure level meter with data-logger (model DEC-490; Instrutherm), with type 2 microphone. It was measured at frequencies from 
63 to $8 \mathrm{kHz}$, with intervals of $1 \mathrm{~s}$ between measurements of the empty and furnished classrooms while school activities occurred normally in adjacent classrooms. Data were collected for $1 \mathrm{~h}$ and the sound pressure level meter was positioned $1.2 \mathrm{~m}$ from the ground, $0.5 \mathrm{~m}$ from movable objects, and $1 \mathrm{~m}$ from the walls and fixed objects. The position chosen was at the back of the classroom near the window, considered the worst situation or the noisiest place of the room. The measurements were based on ANSI S12.60 ${ }^{(5)}$. For data analysis, Microsoft Excel $^{\circledR}$ and Statistical Package for Social Sciences (SPSS) 16.0 were used.

\section{Reverberation time}

Reverberation time is a measure of the degree of reverberation in a space, and is equal to the time required for a constant sound to decay into $60 \mathrm{~dB}$ after the sound source has ceased ${ }^{(16)}$ and is expressed in seconds (s). When the reverberation time has high values, it becomes difficult to distinguish sounds and understand speech because the syllables will overlap and interfere with intelligibility ${ }^{(6)}$.

The reverberation time was evaluated using the impulsive noise method, by popping balloons in six different combinations of microphone and source, according to the engineering method from ISO 3382-2 (2008), and frequencies in octave bands from 125 to $4 \mathrm{kHz}$ were analyzed. The engineering method is used to verify the performance of buildings. The ISO 3382-2 (2008) standard allows the use of two different methods: the interrupted noise method and the impulse response method. The method chosen was impulse response by popping balloons ${ }^{(16)}$.

A TECH BSWA Type 1 omnidirectional microphone, Model $211 \mathrm{MA}$, was used in testing, positioned at a height of $1.2 \mathrm{~m}$ from the ground. The balloon was popped at $1.5 \mathrm{~m}$ from the ground, simulating the height of the teacher's mouth. Data were collected with the help of a National Instruments board and analyzed using Matlab software. The microphone were positioned according to the requirements of ISO 3382-2 $(2008)^{(16)}$ standard, which defines that the microphone should be at a distance of about $1 \mathrm{~m}$ from reflective surfaces, including the floor, and should not be too close to the position of the balloon to avoid the effect of direct sound ${ }^{(16)}$.

The measurement points were as follows:

- Position F1: source (balloon) in the bottom right corner of the room;

- Position F2: source (balloon) in the bottom left corner of the room;

- Position F3: source (balloon) in the left corner to the front of the room;

- Position R1: receiver (microphone) in the left corner to the front of the room;

- Position R2: receiver (microphone) in the bottom right corner of the room;

- Position R3: receiver (microphone) in the bottom left corner of the room.

The six combinations of these microphones and source points used for the measurements were F1R1, F1R3, F2R1, F2R2, F3R2, F3R3.
Measurements were performed during the weekends when the entire school was empty. The measurement and analysis of the reverberation time is in accordance with ISO 3382-2 (2008) standard ${ }^{(16)}$. We chose to measure the value of $\mathrm{T}_{30}$, that is, the decay by $30 \mathrm{~dB}$ of the sound after the sound source ceased, and to extrapolate the value to $\mathrm{T}_{60}$, as it is usually performed on measurements of the reverberation time. The values of the reverberation time were obtained for each frequency band. However, generally, a single value is calculated to express the reverberation time of a room. This value is the arithmetic mean for the frequencies of 500 , 1,000 , and $2,000 \mathrm{~Hz}$.

\section{Speech Transmission Index}

The STI varies between 0 and 1 , and it is used to express the quality of the speech transmission with respect to intelligibility in a speech transmission channel ${ }^{(17)}$. The closer the value to 1 , the higher the quality of the intelligibility of the room ${ }^{(18)}$.

For the measurement of the STI, the IEC 60268-16 (2011) standard presents two methods: direct and indirect. In this study, we chose the indirect method, which uses impulse response to obtain the modulation transfer function and uses the Schroeder equation ${ }^{(18)}$.

The modulation transfer, which is the basis for the STI, may be computed from the impulsive response of a transmission channel using the process known as the Schroeder method. The octave bands from 125 to $8 \mathrm{kHz}$, which should be considered in the method of impulse response, were evaluated ${ }^{(18)}$.

\section{Evaluation of speech intelligibility and students' hearing memory}

Speech intelligibility is the ability of recognition by the hearer of the acoustic signal emitted by the speaker. It is typically expressed in terms of percentage, and the higher the index, the greater the understanding of the acoustic signal. Values close to $100 \%$ are desired to provide better conditions for teaching and learning.

A test of speech intelligibility was applied to students of the classrooms assessed acoustically. A total of 273 students participated in the study, with a mean age of 9.43 years and a median of 9.0 years ( $45.4 \%$ boys and $54.6 \%$ girls).

The intelligibility test was administered to students in their classroom, in diotic listening. The test was adapted from the Speech Recognition Percentage Index test, which is used to perform speech audiometry of patients. It consists of a list of 25 monosyllables, phonetically balanced in accordance with the sounds of the Portuguese language ${ }^{(19)}$. The test material (25 monosyllables) was recorded by a female speaker in an acoustically treated laboratory using the Audacity program. The speech material was recorded on a CD and played in diotic listening through a stereo, in a sound intensity of $65 \mathrm{~dB}$, vocal intensity generally used by a teacher to speak with students without vocal effort ${ }^{(9)}$.

Each student received an answer sheet consisting of three lists with 25 monosyllables each. At the sound of the 
monosyllable, the children should mark the monosyllable they heard with a symbol X, from a closed set containing thee response options. From the results, the percentage of correct answers was calculated, and the speech intelligibility index (SII) was created, so that answers could be qualified. The index was analyzed as follows:

$\mathrm{IIF}=\left(\mathrm{N}_{\text {(correct answers) }} \times 100\right) / 25$

where SII is the speech intelligibility index and $N_{\text {(correct answers) }}$ the number of monosyllables properly recognized by the child.

Children with attention deficit disorder; hearing, visual, or motor impairments identified by the teacher; or absence of informed consent were excluded from the study.

A pilot study was conducted in a classroom of one of the schools participating in the study to assess the adequacy of instruments to collect research data and the form of the testing in the classrooms in diotic listening, making the necessary adjustments. The tests used are standardized for use in an acoustic booth, with headphones and dichotic listening. However, as the purpose of this study was to evaluate the child's performance amid the noise present in the classroom, the tests were adapted for this purpose.

\section{Data analysis}

For input, processing, and quantitative data analysis, the SPSS software, version 16.0, was used. For the descriptive analysis, frequency distribution was performed with the categorical variables involved in the assessment of children in the study, as well as analysis of measures of central tendency and dispersion of continuous variables. In the statistical analysis, $\chi^{2}$-test and Fisher's exact test were used to detect differences between proportions, and Student's $t$-test was used for the analysis of continuous variables. The level of significance was $\mathrm{p} \leq 0.05$.

For data analysis, the $L_{\text {eq }}$ variable was categorized based on the median value of $60 \mathrm{~dB}(\mathrm{~A})$ : classrooms with average noise, up to $60 \mathrm{~dB}(\mathrm{~A})$; classrooms with high noise, above $60 \mathrm{~dB}(\mathrm{~A})$. Therefore, the results of students in speech intelligibility tests in classrooms with less noise, up to $60 \mathrm{~dB}(\mathrm{~A})$, were compared with the performance of students in classrooms with high noise, above $60 \mathrm{~dB}(\mathrm{~A})$.

For the reverberation time analysis, this variable was also categorized based on the median value $(0.88 \mathrm{~s})$, with the division of classrooms into two groups: classrooms with reverberation time up to and more than $0.88 \mathrm{~s}$.

For purposes of inferential analysis, classrooms were divided into two groups: classrooms with STI less than or equal to 0.65 and those with STI above 0.65 , this being the median value.

\section{RESULTS}

The values of $L_{\mathrm{eq}}$ measured in empty and furnished classrooms ranged from 54.51 to $74.04 \mathrm{~dB}(\mathrm{~A})$, with a median of $60 \mathrm{~dB}(\mathrm{~A})$.
The values of $\mathrm{T}_{30}$ in the classrooms analyzed, considering the average of $500,1,000$, and $2,000 \mathrm{~Hz}$, ranged from 0.69 to $2.09 \mathrm{~s}$, with a median of $0.88 \mathrm{~s}$.

The values of STI ranged from 0.47 to 0.70 with a median of 0.65 , and thus are evaluated according to the subjective STI classification of the IEC 60268-16 (2011) standard between "reasonable" (from 0.45 to 0.60 ) and "good" (from 0.60 to 0.75 ).

The distribution of the values of $L_{\mathrm{eq}}, \mathrm{T}_{30}$, and STI can be seen in Figure 1.

The results of students in the intelligibility test by age group can be seen in Table 1 .
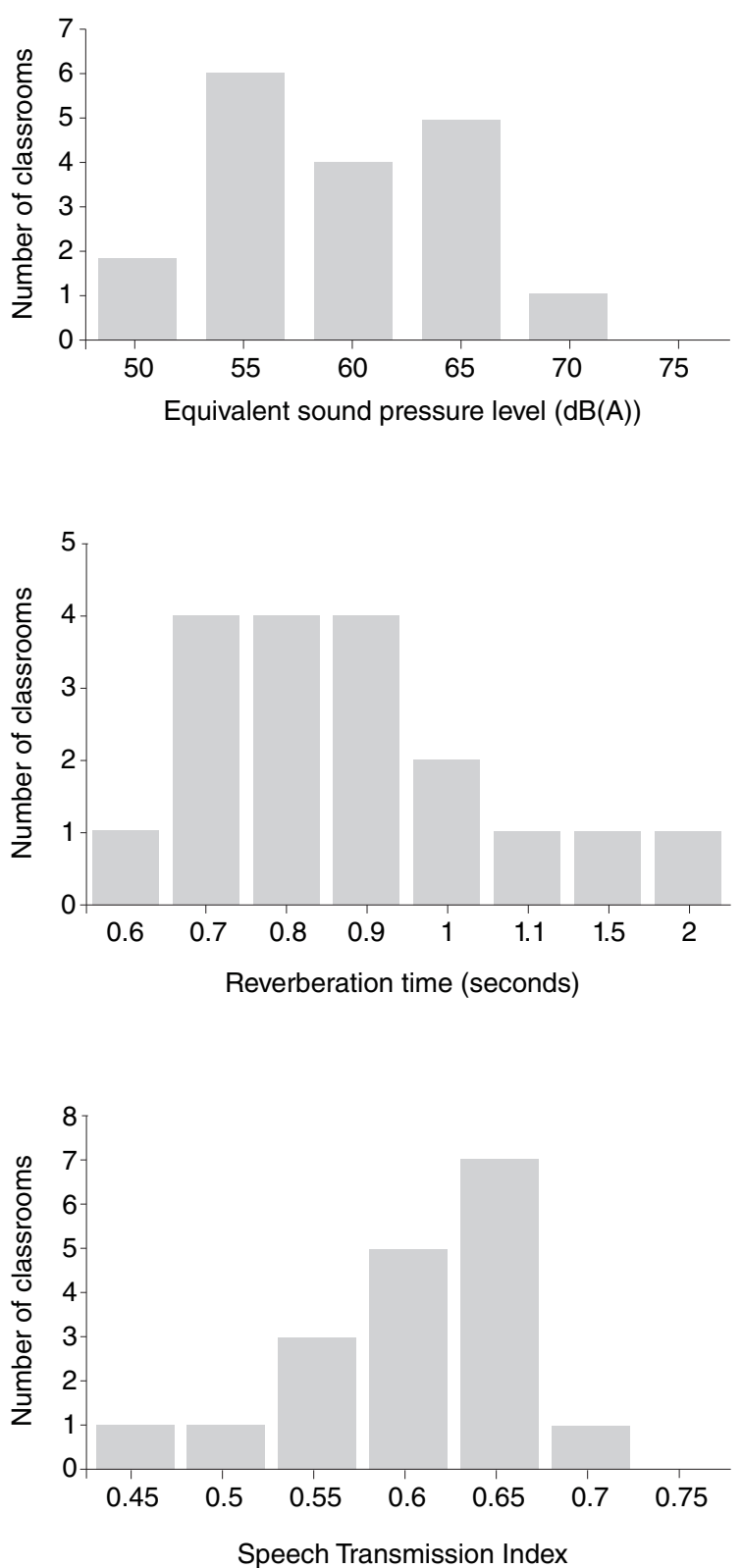

Figure 1. Acoustic measurements of 18 classrooms in the municipality of Belo Horizonte, 2012 


\section{Relationship between the acoustic parameters and test results of children}

When analyzing the results of children in the speech intelligibility test, we found that in classrooms with noise (equivalent sound pressure) less than or equal to $60 \mathrm{~dB}(\mathrm{~A})$, children had better results, with statistical significance (Table 2). Regarding other parameters, students performed better in classrooms with reverberation time up to $0.88 \mathrm{~s}$ and STI greater than 0.65 (Table 2).

\section{DISCUSSION}

This study sought to relate the performance of students on a speech intelligibility test to acoustic parameters of the classroom, which was pioneering in the national scenario. One of the difficulties encountered was the lack of a standardized and validated instrument, capable of measuring the speech intelligibility of students in a classroom, simulating a real teaching and learning situation. Therefore, we chose to adapt the Speech
Recognition Percentage Index for dichotic listening to a diotic listening situation, taking the necessary precautions in the recording and playback of sounds to students.

In this study, the noise, that is, the $L_{\mathrm{eq}}$, found in classrooms was higher than the maximum level recommended by ANSI S12.60 $0^{(5)}$ and the Bulletin $93^{(6)}$, which is $35 \mathrm{~dB}(\mathrm{~A})$. In other words, all classrooms assessed presented values above the limits acceptable in regulatory standards ${ }^{(5,6)}$. This result indicates that the classrooms in the evaluated schools do not provide the ideal environment for the best performance of the students in school activities. In previous studies, in which the $L_{\mathrm{eq}}$ in classrooms was evaluated, the results resembled those found in this study ${ }^{(4,10,11,13)}$. In some studies, however, the noise level was found to be lower ${ }^{(12,14)}$. In addition to the high levels found, there is an aggravating factor in relation to the characteristics of such noise. It is observed that the noise present in schools is characterized by fluctuations and discontinuity and, therefore, is more detrimental than continuous noise when competing with activities that require concentration. The competing noise during the teaching activities demands a greater cognitive load

Table 1. Speech intelligibility index by age group of 249 students*

\begin{tabular}{|c|c|c|c|c|c|}
\hline Age range (years) & Number of children $(n)$ & Mean of correct answers (\%) & Standard deviation & Minimum & Maximum \\
\hline$\geq 8$ & 87 & 88.05 & 21.10 & 0 & 100 \\
\hline 9 & 57 & 86.25 & 21.21 & 20 & 100 \\
\hline 10 & 52 & 92.23 & 16.33 & 8 & 100 \\
\hline 11 & 36 & 89.58 & 19.74 & 4 & 100 \\
\hline 12 & 17 & 91.06 & 17.97 & 36 & 100 \\
\hline All children & 249 & 88.19 & 20.57 & 0 & 100 \\
\hline
\end{tabular}

*Twenty-four children who did not state their age on the test sheet were excluded from the data analysis

Table 2. Association between the values of equivalent sound pressure level, reverberation time, and Speech Transmission Index and the students results of the speech intelligibility test

\begin{tabular}{|c|c|c|c|c|}
\hline Characteristics & Intelligibility index & Mean difference & $t$-test & p-value \\
\hline \multicolumn{5}{|c|}{ Equivalent sound pressure level $\left(\mathrm{L}_{\text {eq }}\right)$} \\
\hline \multicolumn{5}{|c|}{ Average (up to $60 \mathrm{~dB})(\mathrm{n}=120)$} \\
\hline Mean & 91.6 & & & \\
\hline Standard deviation & 18.2 & 6.1 & 2.47 & $0.01^{*}$ \\
\hline \multicolumn{5}{|c|}{ High (above $60 \mathrm{~dB})(\mathrm{n}=152)$} \\
\hline Mean & 85.4 & & & \\
\hline Standard deviation & 21.9 & & & \\
\hline \multicolumn{5}{|l|}{ Reverberation time $\left(\mathrm{T}_{30}\right)$} \\
\hline \multicolumn{5}{|l|}{ Up to $0.88 \mathrm{~s}(\mathrm{n}=154)$} \\
\hline Mean & 90.65 & & & \\
\hline Standard deviation & 19.07 & 6.1 & 2.47 & $0.024^{*}$ \\
\hline \multicolumn{5}{|l|}{ Above $0.88 s(n=118)$} \\
\hline Mean & 84.99 & & & \\
\hline Standard deviation & 22.05 & & & \\
\hline \multicolumn{5}{|c|}{ Speech Transmission Index (STI) } \\
\hline \multicolumn{5}{|c|}{ Up to $0.65(n=158)$} \\
\hline Mean & 84.87 & & & \\
\hline Standard deviation & 22.31 & -7.94 & 2.47 & $0.002^{*}$ \\
\hline \multicolumn{5}{|l|}{ Above $0.65(n=114)$} \\
\hline Mean & 92.81 & & & \\
\hline Standard deviation & 16.92 & & & \\
\hline
\end{tabular}

*Statistically significant values $(\mathrm{p} \leq 0.05)-$ Student's $t$-test 
and, consequently, generates mental fatigue, especially when the task is based on auditory information ${ }^{(20)}$.

Regarding the reverberation time, ANSI S12.60 $0^{(5)}$ and Bulletin $93^{(6)}$ determine that the ideal value for classrooms is up to $0.6 \mathrm{~s}$. Thus, all the rooms had reverberation time results above ideal. Failure to comply with the ideal values of reverberation time can undermine good speech intelligibility between students and teachers and can even interfere with the assimilation of the lesson content. Low reverberation time is usually ideal for classrooms ${ }^{(21)}$ and, when it presents high values, it becomes difficult to distinguish sounds and understand speech. This is because syllables will overlap and interfere with intelligibility $^{(6,8)}$. A long reverberation time is inappropriate for places such as classrooms, because the reflected sound will remain a form of reverberation longer than ideal, interfering with the direct sound and reducing intelligibility. Also, it will cause unwanted sounds, such as dragging of chairs and foot movements, which will also remain longer in the room, increasing noise levels ${ }^{(2)}$. Previous study showed that in classrooms with high reverberation time, teachers reported greater discomfort to the room's interior noise than other noises when compared to rooms with medium and short reverberation times ${ }^{(22)}$. In a study conducted in Copenhagen, Denmark, teachers were also asked about things that made them uncomfortable at work, and those who taught in classrooms with long reverberation times $(0.59-0.73 \mathrm{~s})$ realized their less favorable social environment, and teachers in classrooms with short reverberation times (between 0.41 and $0.47 \mathrm{~s}$ ) reported intention to continue working, suggesting that the comfort of the teachers at work can be improved by acoustic interventions to reduce sound reflections ${ }^{(23)}$.

In a study conducted in classrooms at Universidade Federal do Paraná, the reverberation time values found were between 0.6 and $1.1 \mathrm{~s}^{(24)}$, results close to those found in this study. Study performed among speakers of American English showed that younger children, whose classrooms are noisier, tend to be more affected by the combination of noise and reverberation ${ }^{(25)}$.

The values of STI are sorted between 0 and 1, according to the IEC 60268-16 (2011) regulatory standard ${ }^{(18)}$. In this study, the values measured in the classrooms ranged from 0.47 to 0.70 , and were evaluated according to the subjective classification of STI between reasonable (0.45-0.60) and good (0.60-0.75). No room presented great intelligibility, that is, above $0.75^{(18)}$.

Speech intelligibility is critical for the proper development of school activities and communication between teachers and students, and it is important that the acoustic conditions of the rooms provide a good quality of speech transmission. To be able to learn, the children should turn their attention to the main stimulus and ignore the competitive stimulus. For this, they need the auditory processing of information received ${ }^{(1)}$. That is, it is not enough having the hearing thresholds classified as normal, it is necessary that the acoustic signal be transformed into a meaningful message, and for that, being interpreted and analyzed ${ }^{(26)}$. Excessive noise and poor room acoustics can be very harmful in this whole process of hearing and understanding. In addition, some children present auditory processing disorders, which can further increase the difficulties in understanding the spoken message amidst noise.
Previous study conducted in schools of Belo Horizonte, using a simplified auditory processing evaluation, also showed that of a sample of 539 students aged between 4 and 10 years, 27.3\% presented results suggesting auditory processing disorders ${ }^{(27)}$. These students may experience great difficulty in understanding speech amidst noise, damaging their learning situation, which is exacerbated in classrooms with inadequate acoustics.

Regarding the speech intelligibility test applied to students, it was observed that children performed better in classrooms with lower values of $L_{\text {eq }}$, shorter reverberation time, and increased STI, and these associations were statistically significant. These data show that the acoustic parameters directly influence the intelligibility of speech in the classroom and can interfere with the understanding of what is said by the teacher, and may even impair learning. Studies agree with the statement that noise can interfere with activities in the classroom ${ }^{(3,10,13)}$. Chinese study states that the intelligibility of speech depends on the acoustic parameters such as reverberation time, the sound pressure level of the teacher's speech, and the signal/noise ratio ${ }^{(28)}$.

Generally, studies seeking information on speech intelligibility perform only objective measurements, as in the use of acoustic parameter STI, or use word lists applied individually, with the student using headphones. This study adapted the tests for application in group in their classroom, in diotic listening, to bring the test closer to situations in the daily lives of students. Only international studies have used this methodology, but these are also scarce. One study using this type of testing was conducted in Canada ${ }^{(29)}$ and one in Germany ${ }^{(2)}$. The two studies used figures for naming and marking between some options of similar words to assess intelligibility. However, in Germany, the researchers used the variation of the reverberation time in the recording for two virtual situations, one with reverberation time of $0.47 \mathrm{~s}$ (favorable) and the other with that of $1.1 \mathrm{~s}$ (unfavorable). The test also evaluated words mixed with noises found in classrooms and presented binaurally. Speech noise was used with the reading of a text, and also noises from the movement of desks and chairs and step noises without speech noise. The study showed that age and the position of the child in the classroom interfered with the result. In addition, the auditory comprehension of the children was significantly impaired by speech and background noise in the classroom, but background speech impaired hearing and understanding more than the background noise of the room ${ }^{(2)}$. In a study conducted in Canada, the words were also recorded and the signal/noise ratio was varied by modifying the level of the presentation of the speech material. The signal/noise values from 20 to $30 \mathrm{~dB}$ were used to measure intelligibility scores in ideal conditions for students. It was not possible to modify the acoustic conditions of classrooms. The results showed that the signal/ratio of $15 \mathrm{~dB}+$ was not suitable for younger students (age 6) ${ }^{(29)}$.

A study with Chinese students aged 19-24 years compared STI values of four classrooms simulated by computational analysis with the results of the tests applied through headphones. A simulation of different relationships between the signal/noise ratio of the classrooms was made. There was a high correlation between the results of students in the speech intelligibility tests and STI values found in both diotic and 
dichotic listening ${ }^{(30)}$. These results, together with data from this study, show that both the use of parameter STI and word tests performed with students can provide consistent information on speech intelligibility in classrooms. However, it emphasizes the importance of evaluating speech intelligibility with children inside the classroom, as was done in this study, to better assess the real situation to which students are exposed.

It is expected that further studies can also be conducted in other regions of Brazil, so that meticulous acoustic projects be developed and that specific standards for room acoustics may be well founded on real data on the current situation of Brazilian classrooms.

\section{CONCLUSION}

Classrooms evaluated in this study are not compliant with those required by international standards for adequate acoustic conditions for teaching. Furthermore, it was observed that the acoustic parameters directly influence the speech intelligibility of students, and greater attention should be paid to this issue, because an inefficient communication inside the classroom can have negative consequences on schooling and social inclusion of the future professional.

*ATVR assisted in the study design, data collection, interpretation of the collected data, revision of the article and final approval of the published version; JNS and MCM assisted in the study design, supervision of data collection, analysis and interpretation of data collected, revision of the article and final approval of the published version; RCO assisted in study design, revision of the article and final approval of the published version.

\section{REFERENCES}

1. Dreossi RCF, Momensohn-Santos TM. O ruído e sua interferência sobre estudantes em uma sala de aula: revisão de literatura. Pró-Fono R Atual Cient. 2005;17(2):251-8.

2. Klatte M, Lachmann T, Meis M. Effects of noise and reverberation on speech perception and listening comprehension of children and adults in a classroom-like setting. Noise Health. 2010;12(49):270-82.

3. Dreossi RCF, Momensohn-Santos TM. A interferência do ruído na aprendizagem. Rev Psicopedagogia. 2004;21(64):38-47.

4. Gonçalves VSB, Silva LB, Coutinho AS. Ruído como agente comprometedor da inteligibilidade de fala dos professores. Produção. 2009;19(3):466-76.

5. Acoustical Society of America. ANSI S12.60-2010 - American National Standard: Acoustical Performance Criteria, Design Requirements, and Guidelines for Schools. Part 1: Permanent Schools; Melville, NY: Acoustical Society of America; 2010.

6. Department of Education and Skills. Building Bulletin 93. Acoustic Design of Schools: a design guide. London: The Stationery Office; 2003.

7. Associação Brasileira de Normas Técnicas. Norma NBR 10152. Acústicaníveis de ruído para conforto acústico. Rio de Janeiro: ABNT; 1987.

8. Technical Committee on Speech Communication of the Acoustical Society of America. Classroom Acoustics II. Acoustical barriers to learning. Melville, NY: Acoustical Society of America; 2002.

9. Libardi A, Gonçalves CGO, Vieira TPG, Silverio KCA, Rossi D, Penteado RZ. O ruído em sala de aula e a percepção dos professores de uma escola de ensino fundamental de Piracicaba. Distúrb Comun. 2006;18(2):167-78.

10. Eniz A, Garavelli SSL [Internet]. A contaminação acústica de ambientes escolares devido aos ruídos urbanos no Distrito Federal, Brasil. Holos Environment. 2006;6:137-50. [cited 2013 Mar 05]. Available from: http://www.periodicos.rc.biblioteca.unesp.br/index.php/holos/article/ view/561/469.

11. Zannin PHT, Zwirtes DPZ. Evaluation of the acoustic performance of classrooms in public schools. App Acoust. 2009;70:626-35.

12. Guidini RF, Bertoncello F, Zanchetta S, Dragone MLS. Correlações entre ruído ambiental em sala de aula e voz do professor. Rev Soc Bras Fonoaudiol. 2012;17(4):398-404.

13. Seetha P, Karmegam K, Ismail MY, Sapuan SM, Ismail N, Tamil Moli L. Effects to teaching environmente of noise level in school classrooms. JSIR. 2008;67:659-64.

14. Shield B, Dockrell JE. External and internal noise surveys of London primary schools. J Acoust Soc Am. 2004;115(2):730-8.

15. Nascimento LS, Lemos SMA. A influência do ruído ambiental no desempenho de escolares nos testes de padrão tonal de frequência e padrão tonal de duração. Rev CEFAC. 2012;14:390-402.

16. International Organization for Standardization. Acoustics: Measurement of room acoustic parameters. Part 2: Reverberation time in ordinary rooms. Switzerland: ISO; 2008.

17. Greenland EE, Shield BM. A survey of acoustic conditions in semiopen plan classrooms in the United Kingdom. J Acoust Soc Am. 2011;130(3):1399-410.

18. International Electrotechnical Comission. IEC 60268-16 - International Standard: Sound system equipment - Part 16: Objective rating of speech intelligibility by speech transmission index. Switzerland: IEC; 2011.

19. Santos TMM, Russo ICP. Prática da Audiologia Clínica. $4^{a}$ edição. São Paulo: Cortez; 1994.

20. Kjellberg A, Knutsson A, Lindberg L. Noise exposure and auditory effects on preschool personnel. Noise Health. 2012;14(57):72-82.

21. Yang W, Hodgson M. Auralization study of optimum reverberation times for speech intelligibility for normal and hearing-impaired listeners in classrooms with diffuse sound fields. J Acoust Soc Am. 2006;120(2):801-7.

22. Kristiansen J, Lund SP, Nielsen PM, Persson R, Shibuya H. Determinants of noise annoyance in teachers from schools with different classroom reverberation times. J Environ Psychol. 2011;31:383-92.

23. Persson R, Kristiansen J, Lund SP, Shibuya H, Nielsen PM. Classroom acoustics and hearing ability as determinants for perceived social climate and intentions to stay at work. Noise Health. 2013;16(67):446-53.

24. Zannin PHT, Ferreira AMC, Sant'Ana DQ. Comparação do tempo de reverberação e índice de transmissão da fala (STI) em salas de aula construídas em décadas diferentes. Ambiente Construído. 2009;9(3):125-39.

25. Wróblewski M, Lewis DE, Valente DL, Stelmachowicz PG. Effects of reverberation on speech recognition in stationary and modulated noise by school-aged children and young adults. Ear Hear. 2012;33(6):731-44.

26. Ramos CS, Pereira, LD. Processamento auditivo e audiometria de altas frequências em escolares de São Paulo. Pró-Fono R Atual Cient. 2005;17(2):153-64.

27. Rabelo ATV, Friche AML, Silva BSV, Alves CRL, Campos FR, Goulart LMHF. Associação entre processamento auditivo e desvios fonológicos em escolares. In: $27^{\circ}$ Encontro Internacional de Audiologia; 2012; Bauru. Anais; 2012.

28. Peng J. Chinese speech intelligibility at different speech sound pressure levels and signal-to-noise ratios in simulated classrooms. Applied Acoustics. 2010;71(4):386-90.

29. Braley JS, Sato H. The intelligibility of speech in elementary school classrooms. J Acoust Soc Am. 2008;123(4):2078-86.

30. Peng J, Bei C, Sun H. Relationship between Chinese speech intelligibility and speech transmission index in rooms based on auralization. Speech Communication. 2011;53(7):986-90. 